\title{
THE INFLUENCE OF CORTISONE AND ADRENOCORTICO- TROPHIC HORMONE ON BRUCELLOSIS. I. CORTISONE IN EXPERIMENTALLY INFECTED ANIMALS
}

\author{
By ROBERT ABERNATHY AND WESLEY W. SPINK \\ (From the Department of Medicine, University of Minnesota Hospitals and Medical School, \\ Minneapolis, Minn.)
}

(Submitted for publication April 21, 1952; accepted August 21, 1952)

A basic feature of the host-parasite relationship in brucellosis is the intracellular localization of Brucella in the tissues of animals and man (1-6). This intracellular parasitism is a contributing factor in the tendency of the disease to become chronic. Experimental studies have shown that intracellular Brucella organisms are afforded protection against antibiotics, and also against the lethal action of serum $(7,8)$. Brucella organisms in an extracellular position are readily destroyed by antibiotics, and by fresh serum. Prompt elimination of Brucella from the tissues of the host appears to depend, in part at least, upon dislodging the bacteria from their intracellular localization. The report on experimental tuberculosis by Hart and Rees (9) suggested that the host-parasite relationship in brucellosis could be disrupted by cortisone, and Brucella organisms would then be liberated from the cells of the host. The pathogenesis of brucellosis simulates that of tuberculosis in many respects. Of primary importance is the tendency of both tubercle bacilli and Brucella to localize in macrophages. Hart and Rees (9) demonstrated that cortisone enhanced both acute and chronic tuberculosis in mice. There was more dissemination of the infection in the cortisonetreated an:mals; the individual lesions showed more necrosis and caseation, and contained many more tubercle bacilli than were found in the non-treated control animals. Contrary to expectations, preliminary observations revealed that cortisone caused a marked proliferation and dissemination of Brucella organisms in animals with acute brucellosis, but the steroid did not provoke any demonstrable changes in the animals with chronic infections (10). The present studies also provided information for investigations on the influence of adrenocorticotropic hormone in human subjects having acute or chronic Brucella infections.

\section{METHODS OF STUDY}

The effect of cortisone on experimental acute and chronic brucellosis was studied in mice, guinea pigs, and rabbits. Infections were established with a representative strain of Brucella abortus, Brucella suis, and Brucella melitensis, all of which had been isolated from human sources. White male mice weighing approximately 20 gm. were used. The guinea pigs were all males and averaged $300 \mathrm{gm}$. in weight, while white male rabbits weighing around $2 \mathrm{~kg}$. were studied. An animal was considered to have had an acute infection when but five to 15 days had elapsed from the time the bacteria were first introduced. A chronic infection was indicated when a month or more had elapsed. A suspension of cortisone, containing $25 \mathrm{mg}$. per $\mathrm{ml}$, was injected intramuscularly into the thighs, alternating sides from day to day. Sterile physiologic saline solution was injected into control animals. Two different dosage schedules were employed in the animals with acute infections. Under the first schedule, cortisone was administered for three to five days prior to the establishment of infections, and then for five days to two weeks afterwards. Animals were pretreated with cortisone in a manner similar to that of Mogabgab and Thomas (11), who reported that rabbits were more susceptible to infections with group A hemolytic streptococci when pretreated with cortisone. The second schedule of cortisone therapy was started simultaneously with the infection and treatment carried out for two weeks. In the chronically infected animals, cortisone was administered for five days to two weeks.

At the completion of treatment in each group, all of the animals were sacrificed with chloroform. Fortyeight hours prior to death in the guinea pigs and rabbits Brucella antigen (Brucellergen) was introduced intradermally on the abdomen and evidence of a skin reaction ascertained at the time of sacrifice. Each guinea pig was given $0.15 \mathrm{ml}$. of Brucellergen and each rabbit $0.1 \mathrm{ml}$. of Brucellergen. Blood from the hearts was obtained for cultural purposes and for Brucella agglutination tests. Trypticase-soy broth ${ }^{1}$ was used for blood cultures.

\section{RESULTS}

\section{Influence of cortisone on the tissues of normal} animals

When $0.25,0.5$, or $1.0 \mathrm{mg}$. of cortisone was injected daily into mice, each of these doses produced

1 Baltimore Biological Laboratory, Baltimore, Maryland. 
side effects such as decreased physical activity, ruffling of the fur, weight loss, and occasional diarrhea. The gross and microscopic changes in the livers, kidneys, and lungs were similar to those described by Antopol (12), and consisted of disseminated abscesses, which could be differentiated from the granulomatous reaction caused by Brucella. When a dose of $10 \mathrm{mg}$. of cortisone was administered daily to guinea pigs no side effects were elicited, and there were no abscesses noted in the tissues. A dose of $12.5 \mathrm{mg}$. daily of cortisone given to rabbits induced a marked lipemia (13). The administered hormone caused an enlarged and friable liver with a glossy appearance, and the hepatic cells appeared swollen with a clear cytoplasm and the nucleus situated at the periphery. In all three species, cortisone caused a reduction in the size of the spleens, which has been noted by others $(14,15)$. The adrenals were also reduced in weight.

\section{Influence of cortisone on acute brucellosis}

Mice. A group of mice were pretreated with 1 mg. of cortisone daily for five days and then injected intravenously with approximately 100 million $\mathrm{Br}$. suis organisms. Suitable control mice were also observed as seen in Table I, A. It was intended to continue the daily injection of cortisone for two weeks after the animals had been infected, but this dose was too toxic, and the animals died before this period of time. Approximately the same numbers of Brucella were recovered from the livers and spleens of the cortisonetreated group as from the saline-treated animals. Gram-negative coliform organisms were cultured from the livers and spleens of the uninfected corti-

TABLE I

The influence of cortisone on acute brucellosis in mice

A

Animals pretreated with $1 \mathrm{mg}$. of cortisone daily for 5 days before being infected with Brucella suis and then treated for 5 more days after being infected. A control infected group of mice was similarly treated daily with $0.04 \mathrm{ml}$. of sterile physiologic saline solution instead of cortisone. Another control group, but uninfected, was treated with cortisone.

\begin{tabular}{|c|c|c|c|c|c|c|c|c|c|c|c|}
\hline \multirow{2}{*}{ Group } & \multirow{2}{*}{$\begin{array}{l}\text { Number } \\
\text { of animals }\end{array}$} & \multirow{2}{*}{$\begin{array}{c}\text { Average } \\
\text { days of } \\
\text { treatment }\end{array}$} & \multirow{2}{*}{$\begin{array}{c}\text { Average } \\
\text { total days } \\
\text { of infection }\end{array}$} & \multirow{2}{*}{$\begin{array}{l}\text { No. of animals } \\
\text { with Brucella } \\
\text { in heart's } \\
\text { blood at time } \\
\text { of death }\end{array}$} & \multirow{2}{*}{$\begin{array}{l}\text { Average } \\
\text { wt. of } \\
\text { spleens, } \\
\text { grams }\end{array}$} & \multicolumn{2}{|c|}{$\begin{array}{l}\text { No. of animals } \\
\text { with Brucella } \\
\text { cultured from }\end{array}$} & \multicolumn{4}{|c|}{$\begin{array}{l}\text { No. of microscopic lesions per } \\
10 \text { low-power fields in }\end{array}$} \\
\hline & & & & & & Liver & Spleen & Liver & Spleen & Kidney & Lung \\
\hline $\begin{array}{l}\text { Infected-Cortisone } \\
\text { Infected-Saline } \\
\text { Uninfected-Cortisone }\end{array}$ & $\begin{array}{r}20 \\
20 \\
9\end{array}$ & $\begin{array}{l}10 \\
19 \\
14\end{array}$ & $\begin{array}{r}5 \\
15 \\
0\end{array}$ & $\begin{array}{l}0 / 0 \\
6 / 10 \\
0 / 0\end{array}$ & $\begin{array}{l}0.055 \\
0.403 \\
0.050\end{array}$ & $\begin{array}{l}7 / 20 \\
7 / 20 \\
0 / 5\end{array}$ & $\begin{array}{c}8 / 20 \\
11 / 20 \\
0 / 5\end{array}$ & $\begin{array}{r}195 \\
9 \\
3\end{array}$ & $\begin{array}{l}0 \\
0 \\
0\end{array}$ & $\begin{array}{l}0 \\
0 \\
0\end{array}$ & $\begin{array}{l}0 \\
0 \\
0\end{array}$ \\
\hline
\end{tabular}

B

Animals pretreated with $0.5 \mathrm{mg}$. of cortisone daily for 3 days before being infected with $\mathrm{Br}$. suis and then treated for 7 more days after being infected. A control infected group of mice was similarly treated daily with $0.02 \mathrm{ml}$. of saline solution instead of cortisone. Another control group, but uninfected, was treated with cortisone.

\begin{tabular}{l|r|l|l|l|l|l|l|l|l|l|l}
\hline Infected-Cortisone & 26 & 10 & 7 & $7 / 7$ & 0.132 & $8 / 22$ & $8 / 22$ & 87 & 0 & 0 & $2 / 26$ \\
Infected-Saline & 9 & 11 & 8 & $7 / 7$ & 0.368 & $7 / 9$ & $7 / 9$ & 13 & 0 & 0 & $0 / 9$ \\
Uninfected-Cortisone & 4 & 10 & 0 & 0 & - & $0 / 4$ & $0 / 4$ & 0 & 0 & 0 & $0 / 4$ \\
\hline
\end{tabular}

C

Animals splenectomized one year previously; pretreated with $0.5 \mathrm{mg}$. of cortisone daily for 5 days before being infected with $\mathrm{Br}$. suis and then treated for 6 days more after being infected. A control infected group was similarly treated daily with $0.02 \mathrm{ml}$. of saline solution instead of cortisone.

\begin{tabular}{l|l|l|l|l|l|l|l|l|r|r|r}
\hline Infected-Cortisone & 5 & 11 & 6 & $4 / 4$ & - & $4 / 5$ & - & 110 & - & 1 & 6 \\
Infected-Saline & 4 & 11 & 6 & $4 / 4$ & - & $4 / 4$ & - & 27 & - & 10 & 8 \\
\hline
\end{tabular}

D

Treatment with cortisone started at the same time that animals were infected with $\mathrm{Br}$. suis. One mg. of cortisone was given daily for average of 12 days; a control group of infected animals received $0.04 \mathrm{ml}$. of saline solution.

\begin{tabular}{|c|c|c|c|c|c|c|c|c|c|c|c|}
\hline $\begin{array}{l}\text { Infected-Cortisone } \\
\text { Infected-Saline }\end{array}$ & $\begin{array}{r}10 \\
8\end{array}$ & $\begin{array}{l}12 \\
14\end{array}$ & $\begin{array}{l}12 \\
14\end{array}$ & $\begin{array}{l}0 / 1 \\
5 / 7\end{array}$ & $\begin{array}{l}0.069 \\
0.267\end{array}$ & $\begin{array}{l}4 / 10 \\
2 / 8\end{array}$ & $\begin{array}{l}5 / 10 \\
7 / 8\end{array}$ & $\begin{array}{l}74 \\
16\end{array}$ & $\begin{array}{l}0 \\
0\end{array}$ & $\begin{array}{l}0 \\
0\end{array}$ & $\begin{array}{l}0 \\
0\end{array}$ \\
\hline
\end{tabular}


sone-treated control animals that died. Gross abscesses were noted in the livers, spleens, and lungs of all the animals treated with cortisone. Brucella were recovered from only the livers and spleens. The outstanding observation in this experiment was the appearance of the livers in the Brucella-infected mice that had received cortisone; they were riddled with abscesses, many displaying such a degree of necrosis that structural detail was obliterated. The pronounced destruction of the hepatic tissue caused by cortisone was in marked contrast to the benign type of lesion induced by the injection of saline solution in which an occasional cellular infiltrate occurred without necrosis. The contrasting appearance of the hepatic lesions in the saline-treated animals and the cortisonetreated animals can be seen by comparing Figures 1 and 2. Giemsa-stained preparations of the livers from the cortisone-treated group revealed a striking appearance. The lesions appeared to be teeming with massive numbers of small, gramnegative, cocco-bacillary organisms, arranged in clumps, and giving the typical appearance of Brucella. That these organisms were Brucella was proved by isolation on agar media. The cytoplasm of the hepatic cells was packed with organisms. Many Kupfer cells also contained similar bacteria. In the livers from several animals, there were clumps of organisms in the hepatic sinusoids with no apparent cellular reaction around them. In the saline-treated infected animals, only rare bacteria

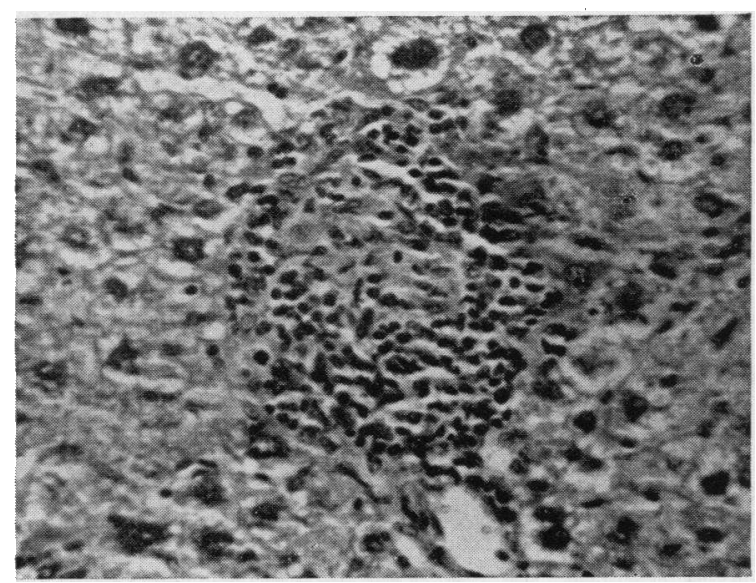

Fig. 1. Focal Inflammatory Lesion without NecroSIS IN THE LIVER OF A Mouse INFECted With $B r$. suis and Pretreated with Physiologic Saline Solution

Hematoxylin and eosin, $300 \times$.

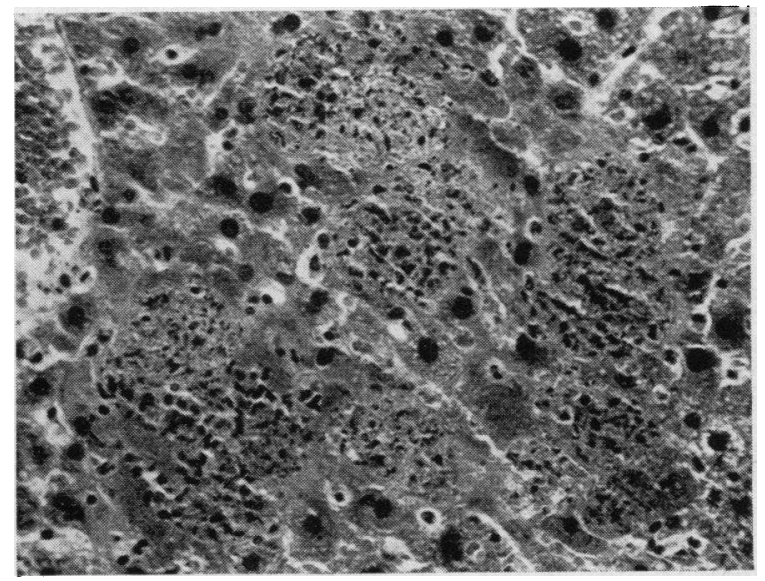

Fig. 2. Massive Inflammatory Reaction and NeCrosis of Hepatic Lesions of Mouse Pretreated with 1 Mg. of Cortisone Daily for Five Days and Then InFECTED WITH $\mathrm{Br}$. suis

Hematoxylin and eosin, $300 \times$.

were seen, and then only after considerable searching. When bacteria were present they were observed in the individual lesions, and none were seen in the parenchymal cells. In the uninfected cortisone-treated controls, bacteria were seen only in the abscesses. There was no essential difference noted in the gross and microscopic appearance of the spleens from the Brucella-infected mice treated with cortisone or with saline solution. The extensive hepatic involvement was absent.

Because a pretreatment dose of $1 \mathrm{mg}$. of cortisone daily for five days proved to be too large, smaller doses of 0.5 and $0.25 \mathrm{mg}$. were administered daily, but even these doses proved too large since the animals died before the expiration of the two weeks' period of treatment. It was then decided to reduce the pretreatment time from five to three days in a group of mice infected with Brucella, giving $0.5 \mathrm{mg}$. of cortisone daily for three days. This schedule also resulted in the premature deaths of the animals. The data of this experiment are presented in Table I, B. Br. suis was recovered from the heart's blood of all the sacrificed, infected animals. It is to be noted that the spleens of the cortisone-treated animals were three times smaller than those that had received saline solution, but the spleens of the animals that had received $0.5 \mathrm{mg}$. of cortisone were twice as large as the spleens of the mice given $1 \mathrm{mg}$. of cortisone daily. Abscesses were noted in the spleens and livers of the 
TABLE II

The influence of cortisone on acute brucellosis in guinea pigs

A

Three animals pretreated with $10 \mathrm{mg}$. of cortisone daily for 5 days, and then one infected with Br. melitensis, one with $B r$. suis, and one with $\mathrm{Br}$. abortus. Treatment continued with cortisone for 5 more days. Three similarly infected animals treated in same way with saline solution.

\begin{tabular}{|c|c|c|c|c|c|c|c|c|c|c|c|}
\hline \multirow{2}{*}{ Group } & \multirow{2}{*}{$\begin{array}{l}\text { Number } \\
\text { of animals }\end{array}$} & \multirow{2}{*}{$\begin{array}{c}\text { Average } \\
\text { days of } \\
\text { treatment }\end{array}$} & \multirow{2}{*}{$\begin{array}{c}\text { Average } \\
\text { total days } \\
\text { of infection }\end{array}$} & \multirow{2}{*}{$\begin{array}{l}\text { No. of animals } \\
\text { with Brucella } \\
\text { in heart's } \\
\text { blood at time } \\
\text { of death }\end{array}$} & \multirow{2}{*}{$\begin{array}{l}\text { Average } \\
\text { wt. of } \\
\text { spleens, } \\
\text { grams }\end{array}$} & \multicolumn{2}{|c|}{$\begin{array}{l}\text { No. of animals } \\
\text { with Brucella } \\
\text { cultured from }\end{array}$} & \multicolumn{4}{|c|}{$\begin{array}{l}\text { No. of microscopic lesions per } \\
10 \text { low-power fields in }\end{array}$} \\
\hline & & & & & & Liver & Spleen & Liver & Spleen & Kidney & Lung \\
\hline $\begin{array}{l}\text { Infected-Cortisone } \\
\text { Infected-Saline }\end{array}$ & $\begin{array}{l}3 \\
3\end{array}$ & $\begin{array}{l}10 \\
10\end{array}$ & $\begin{array}{l}5 \\
5\end{array}$ & $\begin{array}{l}0 / 3 \\
0 / 3\end{array}$ & $\begin{array}{l}0.92 \\
0.88\end{array}$ & $\begin{array}{l}2 / 3 \\
2 / 3\end{array}$ & $\begin{array}{l}3 / 3 \\
3 / 3\end{array}$ & $\begin{array}{l}7 \\
1\end{array}$ & $\begin{array}{l}0 \\
0\end{array}$ & $\begin{array}{l}\mathbf{0} \\
\mathbf{0}\end{array}$ & $\begin{array}{l}0 \\
0\end{array}$ \\
\hline
\end{tabular}

B

Animals pretreated with $10 \mathrm{mg}$. of cortisone daily for 5 days, infected with $\mathrm{Br}$. suis, and then treated for an average of 11 days more. A control group of infected animals was treated in similar manner with daily injections of saline solution.

\begin{tabular}{l|l|l|l|l|l|l|l|l|l|l|l|l}
\hline Infected-Cortisone & 5 & 16 & 11 & $3 / 3$ & 1.09 & $4 / 5$ & $4 / 5$ & 4 & 1 & 0 & - \\
Infected-Saline & 5 & 19 & 14 & $3 / 5$ & 2.80 & $5 / 5$ & $5 / 5$ & 9 & 13 & 0 & - \\
\hline
\end{tabular}

cortisone-treated group, and many more colonies of $\mathrm{Br}$. suis were recovered from the organs of these animals than from the saline-treated group. The extent of liver injury was less in the group of animals receiving $0.5 \mathrm{mg}$. of cortisone daily than in those treated with $1 \mathrm{mg}$. daily. Though there was more cellular infiltration in the cortisone-treated than in the saline-treated group, extensive hepatic necrosis and marked reproduction of brucella cells were absent.

Since the administration of cortisone to mice was uniformly associated with a marked diminution in the size of the spleen, this gave rise to speculation concerning the effect of cortisone on the course of brucellosis in splenectomized mice. Nine healthy mice splenectomized more than a year previously were available for study. Five were pretreated for five days with $0.5 \mathrm{mg}$. of cortisone daily, and four received saline solution. After infection with $\mathrm{Br}$. suis, treatment was continued for six more days and the animals were sacrificed. The results are presented in Table I, C. Brucella organisms were recovered from the heart's blood of all nine animals, and more colonies were isolated from the livers of the cortisone-treated animals. Microscopically, the liver, kidneys, and lungs from all the splenectomized mice showed much more extensive involvement by Brucella than has been described elsewhere for intact animals (16). While the livers of the splenectomized animals treated with cortisone displayed more lesions, there was no essential difference in the histologic appearance of the two groups. There was an absence of highly destructive and necrotic hepatic lesions, and lack of evidence of marked proliferation of the Brucella organisms.

In all the preceding experiments, mice were treated with cortisone before infecting them with Brucella. Observations were made with a group of animals in which the institution of an infection and treatment with cortisone or saline solution were initiated simultaneously. Infected mice received $1 \mathrm{mg}$. of cortisone daily for a mean survival time of 12 days. The results are presented in Table I, D. More colonies of Brucella were cultured on agar plates from the livers of the cortisone-treated animals than from the saline-treated controls. In addition, more extensive involvement of the livers was noted in the cortisone-treated group, but the hepatic necrosis, evidence of suppuration and proliferation of Brucella organisms, was not as pronounced as in the animals that had been pretreated with cortisone.

Guinea pigs. Braude (17) had previously demonstrated in this laboratory that each of the three species of Brucella produced a different reaction in guinea pigs. Therefore, three pairs of guinea pigs were treated in the following manner: one animal in each pair was pretreated with $10 \mathrm{mg}$. of cortisone daily for five days, and then each of these animals was infected intraperitoneally with $\mathrm{Br}$. melitensis, $\mathrm{Br}$. suis, and $\mathrm{Br}$. abortus, respectively, and treatment continued for an additional five days. Three control animals were handled in a 
similar way except that saline solution was given instead of cortisone. The results are presented in Table II, A. No agglutinins were demonstrated in the blood of any of the animals. Although cultures of the heart's blood remained sterile, brucella organisms were recovered from the livers and spleens with more colonies being isolated from the cortisone-treated group. There was no essential difference in the brucella lesions noted in the two groups, except in two animals infected with $\mathrm{Br}$. suis. In the livers of the saline-treated animals, small granulomas without necrosis were observed, whereas in the cortisone-treated animals many more lesions were seen and necrosis was apparent.

A larger number of guinea pigs were then pretreated with cortisone and infected with $\mathrm{Br}$. suis. The results are found in Table II, B. The skin of none of the animals reacted to the intradermal injection of Brucella antigen. Brucella organisms were recovered from the heart's blood of the three surviving cortisone-treated animals, and from three of five saline-treated guinea pigs. Agglutinins were present in all the animals, there being no difference between the two groups. The spleens of the cortisone-treated animals weighed considerably less than the saline-control group. Brucella cells were uniformly isolated from the organs of all the animals sacrificed. More colonies were found in cultures from the cortisone-treated group. Cultures of the organs of those animals that died were overgrown with coliform bacteria. Micro- scopically, the livers and spleens revealed no difference between the two groups of animals in the number, size, and type of lesions and there was no difference in the number of organisms.

Rabbits. In an exploratory type of experiment with each of the three species of Brucella, similar to that carried out with guinea pigs, one in each of three pairs of rabbits was pretreated with 12.5 mg. of cortisone daily for five days, infected, and then treated for an additional five days. The other infected animal in each pair was treated with saline solution. The results are summarized in Table III, A. The intradermal reaction to Brucella antigen was positive in the three saline-treated rabbits, but only slightly positive in one of the cortisone-treated animals and absent in the other two. There was also a significant reduction in the agglutinin titer of the cortisone-treated animals compared to those receiving saline solution. The weight of the spleens was markedly reduced in the cortisone-treated group. Cultures of the organs from all the rabbits yielded Brucella, with more colonies from the cortisone-treated animals. The only significant changes in the tissues occurred in the livers. In the saline-treated group, there were small granulomas without necrosis, but in the cortisone-treated rabbits the number of lesions was not only increased, but considerable necrosis of the hepatic cells with an infiltrate of polymorphonuclear neutrophiles was apparent (Figure 3). Bacteria were seen only in the hepatic lesions of the

TABLE III

The influence of cortisone on acute brucellosis in rabbits

A

Three animals pretreated with $12.5 \mathrm{mg}$. of cortisone daily for 5 days, and then one infected with $B r$. melitensis, one with $B r$. suis, and one with Br. abortus. Treatment with cortisone was continued for 5 days more. Three similarly infected animals were treated in same way with saline solution.

\begin{tabular}{|c|c|c|c|c|c|c|c|c|c|c|c|}
\hline \multirow{2}{*}{ Group } & \multirow{2}{*}{$\begin{array}{c}\text { Number } \\
\text { of animals }\end{array}$} & \multirow{2}{*}{$\begin{array}{c}\text { Average } \\
\text { days of } \\
\text { treatment }\end{array}$} & \multirow{2}{*}{$\begin{array}{c}\text { Average } \\
\text { total days } \\
\text { of infection }\end{array}$} & \multirow{2}{*}{$\begin{array}{l}\text { No. of animals } \\
\text { with Brucella } \\
\text { in heart's } \\
\text { blood at time } \\
\text { of death }\end{array}$} & \multirow{2}{*}{$\begin{array}{l}\text { Average } \\
\text { wt. of } \\
\text { spleens, } \\
\text { grams }\end{array}$} & \multicolumn{2}{|c|}{$\begin{array}{l}\text { No. of animals } \\
\text { with Brucella } \\
\text { cultured from }\end{array}$} & \multicolumn{4}{|c|}{$\begin{array}{l}\text { No. of microscopic lesions per } \\
10 \text { low-power fields in }\end{array}$} \\
\hline & & & & & & Liver & Spleen & Liver & Spleen & Kidney & Lung \\
\hline $\begin{array}{l}\text { Infected-Cortisone } \\
\text { Infected-Saline }\end{array}$ & $\begin{array}{l}3 \\
3\end{array}$ & $\begin{array}{l}10 \\
10\end{array}$ & $\begin{array}{l}5 \\
5\end{array}$ & $\begin{array}{l}3 / 3 \\
3 / 3\end{array}$ & $\begin{array}{l}1.13 \\
2.15\end{array}$ & $\begin{array}{l}3 / 3 \\
3 / 3\end{array}$ & $\begin{array}{l}3 / 3 \\
3 / 3\end{array}$ & $\begin{array}{r}53 \\
9\end{array}$ & $\begin{array}{l}0 \\
0\end{array}$ & - & - \\
\hline
\end{tabular}

B

Animals pretreated with $12.5 \mathrm{mg}$. of cortisone daily for 5 days, infected with $\mathrm{Br}$. suis, and then treated with cortisone for 14 days more. Infected control group was treated in similar manner with saline solution.

\begin{tabular}{l|l|l|l|l|l|l|l|l|l|l|l|l}
\hline Infected-Cortisone & 5 & 18 & 13 & $4 / 4$ & 1.55 & $4 / 4$ & $4 / 4$ & 27 & 48 & 0 & - \\
Infected-Saline & 5 & 19 & 14 & $5 / 5$ & 8.12 & $3 / 5$ & $4 / 5$ & 23 & 40 & 0 & - \\
\hline
\end{tabular}




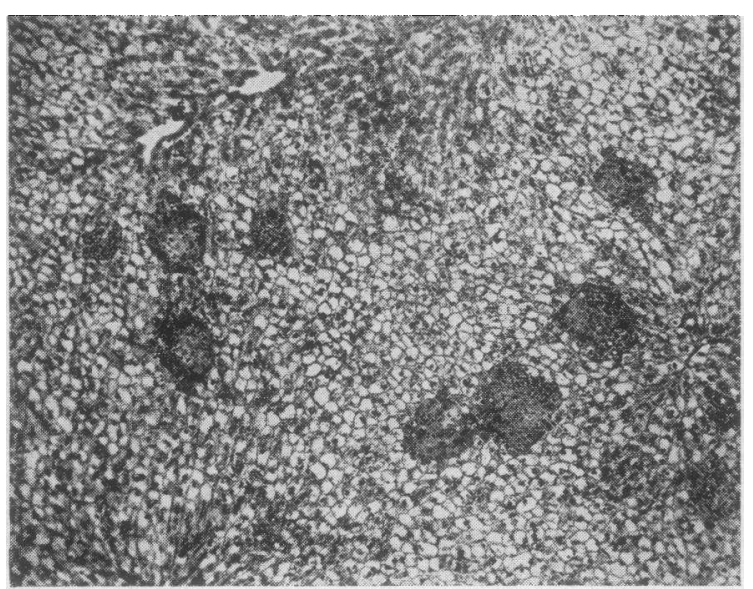

Fig. 3. Liver from Rabbit Pretreated with 1 Mg. of Cortisone Daily for Five Days and Then Infected with $B r$. suis. Animal. Sacrificed on Fifth Day of INFECTION

Note the clear parenchymal cells with nuclei at the side. Several small granulomata with central necrosis. Hematoxylin and eosin, $60 \times$.

cortisone-treated animals that had been infected with $\mathrm{Br}$. melitensis and $\mathrm{Br}$. suis. Organisms were noted in the hepatic cells of the rabbits infected with $B r$. melitensis.

A larger group of rabbits was then pretreated with cortisone, infected with $\mathrm{Br}$. suis, and then treated for another two weeks. One cortisonetreated rabbit died on the eighth day of the infec-

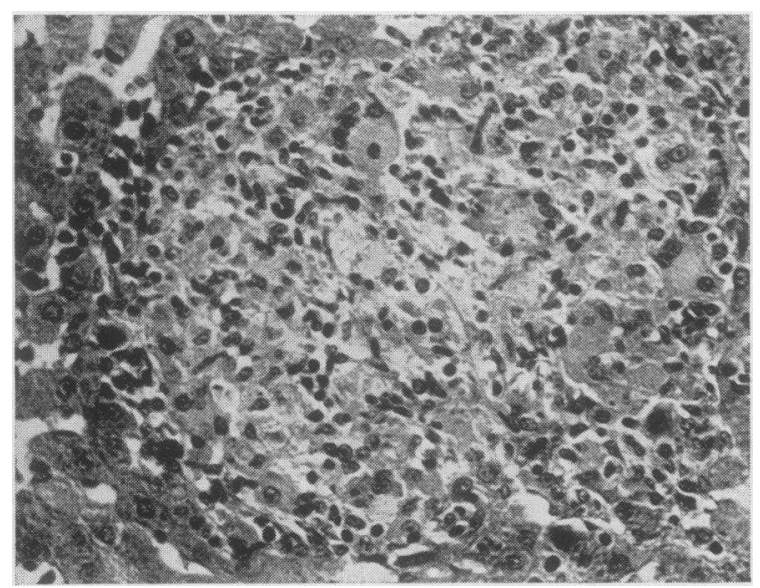

Fig. 4. Liver from Rabbit Pretreated with Saline Solution and then Infected With $\mathrm{Br}$. suis

Animal sacrificed after infection had endured for two weeks. Lesion shows an absence of necrosis and no polymorphonuclear leukocytes are included in the infiltration. Hematoxylin and eosin, $300 \times$. tion, and two were critically ill at the time they were sacrificed on the fourteenth day. Just prior to death the Brucella skin test was negative in all the animals. Colonies of $\mathrm{Br}$. suis were recovered from the bloods of all the animals that had survived the infection for two weeks (Table III, B). Agglutinins for Brucella were present in all the animals, and there was no difference in titer between the cortisone- and saline-treated groups. The weights of the spleens in the cortisone-treated animals were considerably reduced compared to the saline-treated controls. Colonies of $\mathrm{Br}$. suis were cultured from the livers and spleens of all

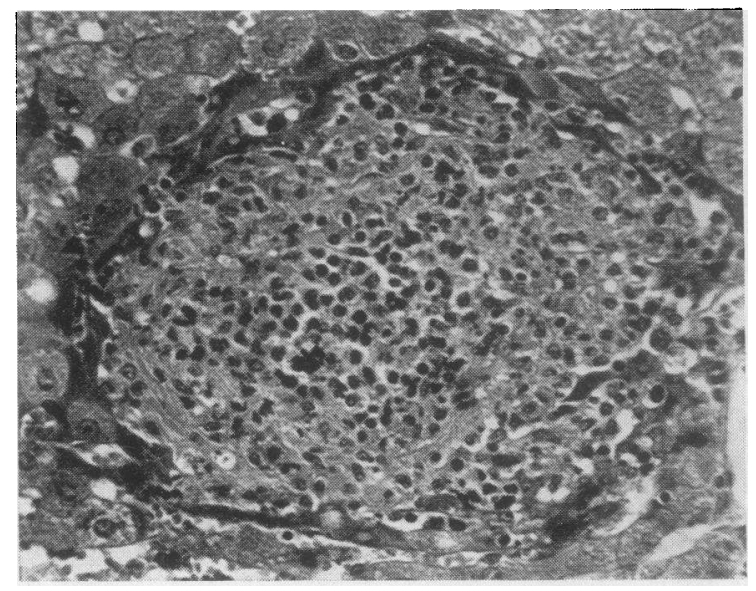

Fig. 5. Hepatic Lesion in Rabbit Pretreated with Cortisone for Five Days and Then Infected with Br. suis

Animals sacrificed after infection had endured for two weeks. At the periphery of the lesion there are mononuclear cells. There is central necrosis with infiltration by polymorphonuclear leukocytes. Hematoxylin and eosin, $300 \times$.

the cortisone-treated rabbits, and in greater numbers than were obtained from the saline-treated animals. The only significant lesions seen were in the livers. While the number of lesions was approximately the same in the cortisone and the saline-treated groups, the hepatic lesions in the cortisone-treated animals showed more necrosis and infiltration with polymorphonuclear leukocytes (Figures 4 and 5).

\section{Infuence of cortisone on chronic brucellosis}

Mice. Mice were each infected with 100 million colonies of $\mathrm{Br}$. suis, and then after a month were given $1 \mathrm{mg}$. of cortisone daily for a mean 
TABLE IV

The influence of cortisone on chronic brucellosis in mice

A

After being infected with $\mathrm{Br}$. suis one month previously, the animals were injected with $1 \mathrm{mg}$. of cortisone daily for an average of 11 days. Control infected animals were treated in similar manner with saline solution for 14 days.

\begin{tabular}{|c|c|c|c|c|c|c|c|c|c|c|c|}
\hline \multirow{2}{*}{ Group } & \multirow{2}{*}{$\begin{array}{c}\text { Number } \\
\text { of animals }\end{array}$} & \multirow{2}{*}{$\begin{array}{c}\text { Average } \\
\text { days of } \\
\text { treatment }\end{array}$} & \multirow{2}{*}{$\begin{array}{c}\text { Average } \\
\text { total days } \\
\text { of infection }\end{array}$} & \multirow{2}{*}{$\begin{array}{c}\text { No. of animals } \\
\text { with Brucella } \\
\text { in heart's } \\
\text { blood at time } \\
\text { of death }\end{array}$} & \multirow{2}{*}{$\begin{array}{l}\text { Average } \\
\text { wt. of } \\
\text { spleens, } \\
\text { grams }\end{array}$} & \multicolumn{2}{|c|}{$\begin{array}{l}\text { No. of animals } \\
\text { with Brucella } \\
\text { cultured from }\end{array}$} & \multicolumn{4}{|c|}{$\begin{array}{l}\text { No. of microscopic lesions per } \\
10 \text { low-power fields in }\end{array}$} \\
\hline & & & & & & Liver & Spleen & Liver & Spleen & Kidney & Lung \\
\hline $\begin{array}{l}\text { Infected-Cortisone } \\
\text { Infected-Saline }\end{array}$ & $\begin{array}{l}12 \\
12\end{array}$ & $\begin{array}{l}11 \\
14\end{array}$ & $\begin{array}{l}41 \\
44\end{array}$ & $\begin{array}{l}0 / 0 \\
1 / 11\end{array}$ & $\begin{array}{l}0.101 \\
0.176\end{array}$ & $\begin{array}{l}1 / 12 \\
2 / 12\end{array}$ & $\begin{array}{l}0 / 12 \\
4 / 12\end{array}$ & $\begin{array}{r}10 \\
7\end{array}$ & $\begin{array}{l}0 \\
0\end{array}$ & $\begin{array}{l}0 / 12 \\
2 / 12\end{array}$ & $\begin{array}{l}0 / 12 \\
1 / 11\end{array}$ \\
\hline
\end{tabular}

B

Mice that had been infected with $B r$. melitensis, Br. suis, or $B r$. abortus 10 to 12 months previous to receiving 4 mg. of cortisone daily for average of 9 days, or $0.16 \mathrm{ml}$. of saline solution for average of 14 days. Two uninfected control mice received $4 \mathrm{mg}$. of cortisone daily for an average of 11 days.

\begin{tabular}{l|r|r|c|c|c|c|c|c|c|c|c}
\hline Infected-Cortisone & 11 & 9 & $10-12$ & $0 / 1^{*}$ & 0.122 & $2 / 11$ & $3 / 9$ & $5 / 11$ & 0 & $0 / 11$ & 0 \\
Infected-Saline & 11 & 14 & $\begin{array}{c}\text { mos. } \\
\text { mos. }\end{array}$ & $1 / 8^{*}$ & 0.304 & $2 / 11$ & $0 / 9$ & $4 / 11$ & 0 & $3 / 11$ & 0 \\
Uninfected-Cortisone & 2 & 11. & - & & 0.040 & 0 & 0 & 0 & 0 & 0 & 0 \\
\hline
\end{tabular}

* Blood from tail.

survival time of 11 days. Infected control mice were treated with saline solution. The data are presented in Table IV, A. The spleens of the cortisone-treated group were smaller than those receiving saline solution. But the outstanding feature was the lack of difference in the appearance of the hepatic lesions in the two groups. Only occasional granulomas were noted, and no bacteria were seen. The administration of relatively large doses of cortisone did not appear to alter the course of a chronic Brucella infection.

A heterogenous group of mice infected and kept in the laboratory for 10 to 12 months were treated as follows : nine mice were infected with $\mathrm{Br}$. melitensis, five receiving $4 \mathrm{mg}$. of cortisone daily and three, $0.16 \mathrm{ml}$. of saline solution; five mice were infected with $\mathrm{Br}$. abortus, two receiving cortisone and two, saline solution in the same doses as above; four mice were infected with $\mathrm{Br}$. abortus following splenectomy, two receiving cortisone and two saline solution; four mice were infected with $B r$. suis, two receiving cortisone and two, saline solution. In addition to these 22 mice, two additional uninfected animals served as controls, each receiving $4 \mathrm{mg}$. of cortisone daily. The data are summarized in Table IV, B. The mean survival time of the cortisone-treated, infected animals was nine days, whereas that of the cortisone controls was 11 days. All the animals receiving saline solu- tion survived the planned period of two weeks with therapy. An attempt was made to obtain blood cultures from each animal toward the end of the period of treatment by clipping the tail and allowing one or two drops of blood to fall on an agar plate. Only one positive blood culture was obtained-from a cortisone-treated animal from which $\mathrm{Br}$. abortus was recovered. At the time the animals were sacrificed, an endeavor was made to obtain sufficient blood for the agglutination reaction and for blood cultures. No agglutinins were demonstrated in the bloods of two cortisonetreated animals, while four of nine mice that had received saline solution showed a mean titer of 1 to 320. The heart's blood of one cortisone-treated animal was cultured and yielded no Brucella organisms, whereas colonies of Brucella were recovered from one of the eight saline-treated mice. The mean weight of the spleens of the infected cortisone-treated group was considerably less than the saline-treated mice. Cultures of the organs for Brucella were positive in three of the cortisonetreated group; two of the animals having positive cultures from both the livers and spleens, and one from the spleen alone. In the saline-treated group, Brucella was isolated from only the livers of two of the animals. Various coliform organisms were recovered from the organs of the uninfected cortisone-treated controls. There was no difference in 
TABLE V

The influence of cortisone on chronic brucellosis in guinea pigs

One guinea pig infected with $B r$. melitensis, one with $B r$. suis, and one with $B r$. abortus. After one month, animals were treated with $10 \mathrm{mg}$. of cortisone daily for 14 days. Three control animals, infected similarly, were treated with saline solution.

\begin{tabular}{|c|c|c|c|c|c|c|c|c|c|c|c|c|}
\hline \multirow{2}{*}{ Group } & \multirow{2}{*}{$\begin{array}{c}\text { Number } \\
\text { of } \\
\text { animals }\end{array}$} & \multirow{2}{*}{$\begin{array}{l}\text { Days of } \\
\text { treatment }\end{array}$} & \multirow{2}{*}{$\begin{array}{l}\text { Days of } \\
\text { infection }\end{array}$} & \multicolumn{2}{|c|}{$\begin{array}{l}\text { Brucella from heart's } \\
\text { blood }\end{array}$} & \multirow{2}{*}{$\begin{array}{c}\text { Average } \\
\text { wt. of } \\
\text { spleens, } \\
\text { grams }\end{array}$} & \multicolumn{2}{|c|}{$\begin{array}{l}\text { No. of animals } \\
\text { with Brucella } \\
\text { cultured from }\end{array}$} & \multicolumn{4}{|c|}{$\begin{array}{l}\text { No. of microscopic lesions per } \\
10 \text { low-power fields in }\end{array}$} \\
\hline & & & & $\begin{array}{c}\text { Before } \\
\text { treatment }\end{array}$ & $\begin{array}{c}\text { After } \\
\text { treatment }\end{array}$ & & Liver & Spleen & Liver & Spleen & Kidney & Lung \\
\hline $\begin{array}{l}\text { Infected-Cortisone } \\
\text { Infected-Saline }\end{array}$ & $\begin{array}{l}3 \\
3\end{array}$ & $\begin{array}{l}14 \\
14\end{array}$ & $\begin{array}{l}42 \\
42\end{array}$ & $\begin{array}{l}2 / 3 \\
1 / 2\end{array}$ & $\begin{array}{l}2 / 3 \\
0 / 2\end{array}$ & $\begin{array}{l}3.23 \\
4.39\end{array}$ & $\begin{array}{l}2 / 3 \\
3 / 3\end{array}$ & $\begin{array}{l}2 / 3 \\
3 / 3\end{array}$ & $\begin{array}{l}3 \\
9\end{array}$ & $\begin{array}{l}3 \\
0\end{array}$ & $\begin{array}{l}0 \\
0\end{array}$ & - \\
\hline
\end{tabular}

the appearance of the splenic and hepatic lesions in either the cortisone-treated animals or in the saline group. Very few hepatic lesions were found in any of the animals, regardless of the type of therapy. When lesions were present, they consisted of small granulomas composed of mononuclear and epithelioid cells, but without giant cells, necrosis or polymorphonuclear leukocytes. Each spleen from the infected animals contained giant cells and a reduced number of germinating follicles, which varied from animal to animal, but there was no correlation between the appearance of the lesions and the type of therapy.

Guinea pigs. Three pairs of guinea pigs were infected intraperitoneally with approximately one billion Brucella cells; one pair receiving $\mathrm{Br}$. suis, one pair $\mathrm{Br}$. melitensis, and one pair $\mathrm{Br}$. abortus. One month later, one animal in each pair was treated with $10 \mathrm{mg}$. of cortisone daily for 14 days, and the three control animals were given saline solution. Just prior to starting therapy, and at the conclusion of five days of treatment, blood was obtained from each animal by cardiac puncture for cultures and for agglutination tests. Table $\mathrm{V}$ summarizes the results of this experiment. There was no essential difference in the results of blood cultures obtained before and after treatment with either cortisone or saline solution; nor was there any significant difference in the agglutinin titers. The skin reaction with Brucella antigen was less in the cortisone-treated animals. The weights of the spleens from the animals that had received cortisone were less than the saline-treated controls, but the differences were not so great as observed in the animals having more acute infections and treated with cortisone (see Table II, A and II, B). Brucella organisms were recovered from the livers and spleens in two out of the three cortisonetreated animals, and from the organs of all three saline-treated controls. There was no significant

TABLE VI

\section{The influence of cortisone on chronic brucellosis in rabbits}

\section{A}

One rabbit was infected with $\mathrm{Br}$. melitensis, one with $\mathrm{Br}$. suis, and one with $\mathrm{Br}$. abortus. After one month, the animals were treated with $12.5 \mathrm{mg}$. of cortisone for 14 days. Three control animals infected similarly were treated with saline solution.

\begin{tabular}{|c|c|c|c|c|c|c|c|c|c|c|c|c|}
\hline \multirow{2}{*}{ Group } & \multirow{2}{*}{$\begin{array}{c}\text { Number } \\
\text { of } \\
\text { animals }\end{array}$} & \multirow{2}{*}{$\begin{array}{l}\text { Days of } \\
\text { treatment }\end{array}$} & \multirow{2}{*}{$\begin{array}{l}\text { Days of } \\
\text { infection }\end{array}$} & \multicolumn{2}{|c|}{$\begin{array}{l}\text { Brucella from heart's } \\
\text { blood }\end{array}$} & \multirow{2}{*}{$\begin{array}{l}\text { Average } \\
\text { wt. of } \\
\text { spleens, } \\
\text { grams }\end{array}$} & \multicolumn{2}{|c|}{$\begin{array}{l}\text { No. of animals } \\
\text { with Brucella } \\
\text { cultured from }\end{array}$} & \multicolumn{4}{|c|}{$\begin{array}{l}\text { No. of microscopic lesions per } \\
10 \text { low-power fields in }\end{array}$} \\
\hline & & & & $\begin{array}{c}\text { Before } \\
\text { treatment }\end{array}$ & $\begin{array}{l}\text { After } \\
\text { treatment }\end{array}$ & & Liver & Spleen & Liver & Spleen & Kidney & Lung \\
\hline $\begin{array}{l}\text { Infected-Cortisone } \\
\text { Infected-Saline }\end{array}$ & $\begin{array}{l}3 \\
3\end{array}$ & $\begin{array}{l}14 \\
14\end{array}$ & $\begin{array}{l}42 \\
42\end{array}$ & $\begin{array}{l}2 / 3 \\
2 / 3\end{array}$ & $\begin{array}{l}1 / 3 \\
0 / 2\end{array}$ & $\begin{array}{l}1.83 \\
2.44\end{array}$ & $\begin{array}{l}0 / 3 \\
2 / 3\end{array}$ & $\begin{array}{l}0 / 3 \\
1 / 3\end{array}$ & $\begin{array}{l}3 \\
1\end{array}$ & $\begin{array}{l}0 \\
2\end{array}$ & $\begin{array}{l}0 \\
0\end{array}$ & - \\
\hline
\end{tabular}

$\mathrm{B}$

After being infected four months previously with $\mathrm{Br}$. abortus, animals were injected with $12.5 \mathrm{mg}$. of cortisone daily for 14 days. One control animal similarly infected was treated with saline solution.

\begin{tabular}{l|l|l|l|l|l|l|l|l|l|l|l|l|l}
\hline Infected-Cortisone & 3 & 14 & 137 & $0 / 3$ & $0 / 3$ & 0.90 & $0 / 3$ & $0 / 3$ & 0 & 0 & 0 & - \\
Infected-Saline & 1 & 14 & 137 & $1 / 1$ & $1 / 1$ & 1.53 & $0 / 1$ & $0 / 1$ & 0 & 0 & 0 & - \\
\hline
\end{tabular}


difference in the number of bacteria obtained from the organs of the two groups, nor in the microscopic examination of the livers, spleens, and kidneys. Only a few small lesions in the livers were seen.

Rabbit. Three pairs of rabbits were infected intravenously with about one and one-half billion Brucella organisms. One pair received $\mathrm{Br}$. melitensis, one pair $\mathrm{Br}$. suis, and one pair $\mathrm{Br}$. abortus. One month later three animals were given $12.5 \mathrm{mg}$. of cortisone daily for 14 days, and three received saline solution. Skin tests performed just before the animals were sacrificed resulted in smaller nodules and less edema in the cortisone-treated rabbits than in the saline-treated controls. Blood obtained by cardiac puncture just before instituting treatment and at the time of sacrifice did not show any significant difference in the blood cultures and agglutination tests in the two groups of rabbits (see Table VI, A). The average weights of the spleens of the cortisone-treated animals were definitely less than the saline-treated controls. Cultures of the livers and spleens from the animals that had received cortisone did not reveal any Brucella, whereas these organisms were cultured from the livers of two of three salinetreated rabbits and from the spleen of one. A very few hepatic lesions were noted microscopically, but there was no difference in the appearance of the lesions in the cortisone-treated and saline-treated animals.

In another experiment with rabbits, animals were treated that had been infected for four months. Infection was established by the intravenous injection of $\mathrm{Br}$. abortus in a total dose of 18.75 billion organisms given in five divided doses. Three of the animals were given $12.5 \mathrm{mg}$. of cortisone daily for 14 days, and one was given $0.5 \mathrm{ml}$. of saline solution for the same period. The results are presented in Table VI, B. Blood obtained by cardiac puncture from the animals before and after treatment with cortisone did not contain any Brucella, but $B r$. abortus was recovered both times from the single saline-treated control. The mean blood agglutinin titer of the cortisone-treated animals was $1: 1,280$ just before treatment, and $1: 160$ at the conclusion of treatment. The titer in the one saline control animal was $1: 2,560$ before treatment, falling to $1: 640$ after therapy. The mean weight of the spleens in the cortisone-treated animals was much less than that of the salinetreated control. No Brucella organisms were recovered from the livers or spleens of any of the animals, and no lesions were seen microscopically in the livers, spleens, and lungs.

\section{DISCUSSION}

The primary objective of the foregoing experiments was to measure the influence of cortisone upon the host-parasite relationship in experimentally infected animals having acute or chronic Brucella infections. Comparative observations were made in mice, guinea pigs and rabbits infected with $\mathrm{Br}$. abortus, $\mathrm{Br}$. melitensis, or $\mathrm{Br}$. suis. In all three species of animals having an acute infection due to $\mathrm{Br}$. suis, cortisone accelerated the multiplication of Brucella in the body and augmented the destruction of tissue, but this enhancement of bacterial dissemination was not so pronounced with $\mathrm{Br}$. abortus and $\mathrm{Br}$. melitensis. The most striking changes were demonstrated in mice having acute brucellosis. Cortisone converted a relatively mild infection into a rapidly fatal disease. The liver best demonstrated the tissue changes induced in these animals. Saline-treated control animals infected with $B r$. suis revealed a moderate number of granulomatous lesions in which little or no necrosis was apparent, and the cellular infiltrate included few or no polymorphonuclear leukocytes. This type of tissue reaction represents a good defense mechanism against invading Brucella. Cortisone abruptly and disastrously altered the host-parasite relationship in favor of the invading Brucella. The Brucella multiplied rapidly as evidenced by an intense parasitization of the hepatic parenchymal cells and an engorgement of the Kupfer cells by bacteria. This was associated with the destruction of the hepatic cells, with necrosis, and an infiltration by polymorphonuclear leukocytes. The deleterious effects of cortisone were accentuated by the larger doses and were most apparent in those animals which received cortisone for a few days before they were infected with Brucella. A similar enhancing effect has been reported by Tempereau and his associates (18) in guinea pigs having acute infections due to $\mathrm{Br}$. abortus and treated with ACTH. It is of interest that in the present experiments cortisone did not appear to effect the course of the disease in guinea pigs, and it pro- 
voked only a moderate enhancement of the infection in the rabbit.

In contrast to the effect of cortisone in acutely infected animals, the steroid failed to disturb significantly the host-parasite balance in the chronically infected animal. Protection of the animal with chronic disease against cortisone may have been afforded by an acquired immune mechanism against Brucella. This immunity could have prevented the multiplication of Brucella and caused the intracellular localization of the remaining organisms. While the administration of cortisone could result in the liberation of the intracellular organisms, an efficient humoral immunity would prevent the multiplication of the Brucella and invasion of other cells of the host.

Hypersensitivity, as measured by the skin reaction with Brucella antigen, was suppressed in the guinea pig and rabbit by cortisone. Suppression of skin reactions in other infections by cortisone and ACTH has been observed (19-21). Cortisone did not appear to cause a consistent change in the titer of Brucella agglutinins, nor did cortisone prevent the appearance of agglutinins in acutely infected animals. Neither ACTH nor cortisone interfere with the production of pneumococcic antibodies $(22,23)$.

One of the consistent side effects of cortisone was the diminution in the size of the spleen in the cortisone-treated animals as compared to the saline-treated group. In a previous study in mice by Braude and Spink (24) it was demonstrated that the spleen apparently protects the liver against Brucella. The hepatic lesions in splenectomized mice were more widespread than in infected control animals with spleens. In the present study, cortisone did not enhance the damage to the liver in splenectomized mice, as compared to the salinetreated animals.

\section{SUMMARY}

1. Cortisone was administered to mice, guinea pigs and rabbits having acute or chronic brucellosis due to $\mathrm{Br}$. abortus, $\mathrm{Br}$. melitensis, or $\mathrm{Br}$. suis. Comparative histopathologic studies of the liver and spleen were made, as well as bacteriologic and immunologic observations.

2. The most striking effects of cortisone were manifested in mice that had acute brucellosis due to $B r$. suis and that were pretreated with the steroid. Under these circumstances, a relatively mild infection in which the liver revealed granulomatous lesions without necrosis was converted into a fulminating and fatal illness with a marked increase in the number of hepatic lesions. Quite impressive was the necrosis and destruction of parenchymal tissue, and Brucella organisms appeared to be multiplying in the hepatic cells and engorging the Kupfer cells.

3. In contrast to the abrupt changes induced in the acutely infected animals, cortisone did not appear to alter the course of the disease nor the tissue reactions in the chronically infected animals. It is suggested that an efficient immune mechanism protected the animals with chronic brucellosis against the enhancing effect of cortisone exhibited in the animals with acute infections.

4. Dermal hypersensitivity to Brucella antigen was suppressed by cortisone in guinea pigs and rabbits. Cortisone did not interfere with the appearance of Brucella agglutinins in the acutely infected animals. The titer of agglutinins in animals with chronic brucellosis was not consistently altered by cortisone.

\section{REFERENCES}

1. Fabyan, M., A contribution to the pathogenesis of B. abortus, Bang II. J. Med. Research, Boston, 1912, 26, 441.

2. Smith, T., A characteristic localization of Bacillus abortus in the bovine fetal membranes. J. Exper. Med., 1919, 29, 451.

3. Goodpasture, E. W., and Anderson, K., The problem of infection as represented by bacterial invasion of the chorio-allantoic membrane of chick embryos. Am. J. Path., 1937, 13, 149.

4. Castaneda, M. Ruiz-, Studies on the pathogenesis of brucellosis. Proc. Soc. Exper. Biol. \& Med., 1947, 64, 298.

5. Meyer, K. F., Observations on the pathogenesis of undulant fever, in Essays in Biology, San Francisco, 1943, University of California Press, pp. 439 452.

6. Braude, A. I., Studies in the pathology and pathogenesis of experimental brucellosis. II. The formation of the hepatic granuloma and its evolution. J. Infect. Dis., 1951, 89, 87.

7. Magoffin, R. L., and Spink, W. W., The protection of intracellular brucella against streptomycin alone and in combination with other antibiotics. J. Lab. \& Clin. Med., 1951, 37, 924.

8. Shaffer, J. M., and Kucera, C., Studies on the biologic significance of the protection afforded intracellular bruçella. J. Clin. Invest., 1952, 31, 661. 
9. Hart, P. D., and Rees, R. J. W., Enhancing effect of cortisone on tuberculosis in the mouse. Lancet, 1950, 2, 391.

10. Abernathy, R., The effect of cortisone on experimental brucellosis. J. Clin. Invest., 1951, 30, 626.

11. Mogabgab, W. J., and Thomas, L., The effects of cortisone on experimental infection with Group A streptococci in rabbits. J. Lab. \& Clin. Med., 1950, 36, 968.

12. Antopol, W., Anatomic changes produced in mice treated with excessive doses of cortisone. Proc. Soc. Exper. Biol. \& Med., 1950, 73, 262.

13. Rich, A. R., Cochran, T. H., and McGoon, D. C., Marked lipemia resulting from the administration of cortisone. Bull. Johns Hopkins Hosp., 1951, 88, 101.

14. Germuth, F. G., Jr., Nedzel, G. A., Ottinger, B., and Oyama, J., Anatomic and histologic changes in rabbits with experimental hypersensitivity treated with Compound E and ACTH. Proc. Soc. Exper. Biol. \& Med., 1951, 76, 177.

15. Molomut, N., Spain, D. M., and Haber, A., The effect of cortisone on the spleen in mice. Proc. Soc. Exper. Biol. \& Med., 1950, 73, 416.

16. Braude, A. I., Studies in the pathology and the pathogenesis of experimental brucellosis. Thesis submitted to Graduate Faculty, University of Minnesota, 1950.

17. Braude, A. I., Studies in the pathology and pathogenesis of experimental brucellosis. I. Compari- son of the pathogenicity of Brucella abortus, Brucella melitensis and Brucella suis for guinea pigs. J. Infect. Dis., 1951, 89, 76.

18. Tempereau, C. E., Rawlings, B., Lack, A., and Carpenter, C. M., Effect of ACTH on experimental brucellosis in guinea pigs. Ann. West. Med. Surg., 1951, 5, 997.

19. Derbes, V. J., Dent, J. H., Weaver, N. K., and Vaughan, D. D., Response of tuberculin skin test to ACTH and cortisone in tuberculous guinea pigs. Proc. Soc. Exper. Biol. \& Med., 1950, 75, 423.

20. Sheldon, W. H., Cummings, M. M., and Evans, L. D., Failure of ACTH or cortisone to suppress tuberculin skin reactions in tuberculous guinea pigs. Proc. Soc. Exper. Biol. \& Med., 1950, 75, 616.

21. Long, J. B., and Favour, C. B., The ability of ACTH and cortisone to alter delayed type bacterial hypersensitivity. Bull. Johns Hopkins Hosp., 1950, 87, 186.

22. Kass, E. H., Ingbar, S. H., and Finland, M., Effects of adrenocorticotropic hormone in pneumonia: Clinical, bacteriological and serological studies. Ann. Int. Med., 1950, 33, 1081.

23. Mirick, G. S., The effect of adrenocorticotrophic hormone and cortisone on antibody production in human beings. J. Clin. Invest., 1950, 29, 836.

24. Braude, A. I., and Spink, W. W., Studies in the pathology and pathogenesis of experimental brucellosis. III. Investigations pertaining to the function of the spleen. J. Infect. Dis., 1951, 89, 272.

\section{SPECIAL NOTICE TO SUBSCRIBERS}

Post Offices will no longer forward the Journal when you move.

Please notify The Journal of Clinical Investigation, Business Office, 622 West 168th Street, New York 32, N. Y. at once when you have a change of address, and do not omit the zone number if there is one. 